\title{
Critical Cost Overrun Factors and its Controlling Measures in Construction Sector of Pakistan
}

\author{
Samiullah Sohu ${ }^{1, *}$, Ashfaque Ahmed Jhatial ${ }^{2}$, Qadir Bakhsh Jamali ${ }^{3}$, Abdul Hafeez Buller ${ }^{4}$, Imtiaz Ali \\ Bhatti $^{5}$ \\ ${ }^{1}$ Department of Civil Engineering, QUEST, Nawabshah, Pakistan \\ ${ }^{2}$ Department of Civil Engineering, MUET, Jamshoro, Pakistan \\ ${ }^{3}$ Department of Mechanical Engineering, QUEST, Nawabshah, Pakistan \\ ${ }^{4}$ Department of Civil Engineering, QUEST, Nawabshah, Pakistan \\ ${ }^{5}$ Faculty of Civil Engineering and Built Environment, Universiti Tun Hussein Onn Malaysia, Parit Raja, Johor, Malaysia. \\ ${ }^{*}$ Corresponding author: engr.samiullah@quest.edu.pk
}

\section{Abstract}

Construction projects facing cost overrun is a common problem in developing countries, including Pakistan. This research paper identifies the major cost overrun factors faced by construction projects in Pakistan and also provides recommendations to reduce the cost overrun. To main objectives of this research is to identify the critical cost overrun factors and its controlling measures. To attain objectives, the first in-depth literature review was conducted, which helped to identify 33 common cost overrun factors. Secondly, a structured questionnaire was established among stakeholders of the construction sector to share feedback about the critical cost overrun factors. Results showed that stakeholders of construction projects (consultant, contractor, and client) have a different perception of cost overrun. After identification of major cost overrun factors, interviews were carried among mostly experienced stakeholders for mitigation and control measures. This research delivers a better understanding of major cost overrun factors. Also, it provides recommendations to stakeholders of construction projects as well as other professionals of Pakistan to control cost overrun.

Keywords-Cost overrun, Controlling measures, Construction sector

\section{Introduction}

$\mathrm{T}$ HE construction industry is known as a very famous industry among all industries, which contributes about 9\% of GDP (Gross Domestic Product) and also $6 \%$ of the employment in Pakistan [1]. Pakistan is known as a developing country due to the complex nature of construction industry. Pakistan is facing many challenges of time overrun, cost overrun, quality standards and poor management in the construction sector [2]. Although, due to advanced technologies in this sector, cost overrun is a severe and critical issue throughout the world [3]. For example, 90\% of the projects of Uganda had faced the issue of cost overrun [4]. However, according to Ojo et. al. [5], almost all types of construction projects of Qatar are affected by

ISSN: 2523-0379 (Online), ISSN: 1605-8607 (Print)

DOI: https://doi.org/10.52584/QRJ.1901.10

This is an open access article published by Quaid-e-Awam University of Engineering Science \& Technology, Nawabshah, Pakistan under CC BY 4.0 International License. the cost overrun.

Rahman et. al. [6] concluded that 8 out of 10 construction projects of Malaysia had cost overrun of an average of $50 \%$ and above. A study carried by Narayanan et. al. [7] states that on average the mega construction projects in India cost more than 35\% higher than the total cost of the project which was set initially. According to Khabisi et. al. [8], only $29 \%$ of the construction projects of South Africa were completed on the approved budget of the project. However, Amri and Marey-Perez [9] state that almost more than $60 \%$ of construction projects of Oman had faced cost overrun. Present studies has exposed the issue of cost overrun in all over the world. Construction sector of Pakistan is facing the critical cost overrun issues since last decades which has affected the economy of Pakistan [10]. It has been observed that many construction projects has faced cost overrun more than $50 \%$ from its original approved cost. Pakistan construction sector is 
severely affected from the serious and critical issue of cost overrun which has caused negative impact on the construction stakeholders [11].

A lot of research has been conducted to identify the factors of cost overrun in different construction projects including Pakistan, but smaller number of studies have been conducted on controlling the factors or causes of critical factors of cost overrun. However, this research has two objectives: one is the identification of critical cost overrun factors, and second is the determination of controlling measures of critical cost overrun factors.

\section{Literature Review}

A wide variety of research has been conducted on causes of cost overrun in construction projects. Wanjari and Dobariya [12] identified the main factors leading to cost overrun in Indian construction projects by conducting a survey. They identified thirteen cost overrun factors. Findings of the survey showed that the main cost overrun factors had cost escalation of construction items, delay in the planning of different phases of construction, coordination among stakeholders of the project, no proper planning of the project, changes in the scope of the project and submission of the redesign of the project. Khabisi et. al. [8] found the most important factors insisting cost overrun in the construction sector of South Africa, namely: variation in orders, cash flow problems, changes and variation in scope of the selected project, delay in making decisions, frequent changes in design, poor planning, improper coordination among parties, and accepting lowest rate tender policy. Akinradewo and Aigbavboa [13] specified the main causes of cost overrun in the construction sector of Nigeria by surveying construction stakeholders. The research outcomes presented that the main cost overrun causes were frequent changes in design, delayed payment to suppliers, improper project management, lack of coordination among construction stakeholders involved in the project, and incompetent additional cost (e.g., variations), poor financial control on-site, contract management, previous experience of the contractor, and wrong estimation method.

Albhaisi et. al. [14] surveyed the critical factors which contribute to cost overrun in Qatar construction projects. Interviews were carried out among 97 construction experts of mega running projects. The outcomes of the interviews exposed that critical cost overrun factors were changed in scope by the client, complex nature of design, client involvement in the design, lack of advanced machinery and safety conditions at site changes. In Vietnam, Kim et. al. [15] conducted a study for the determination of factors leading to cost overrun in the construction sector. A questionnaire was distributed among contractors, client and consultants. The survey revealed that crucial cost overrun factors add work to a contractor, cost of material and its improper order, price inflation, delay in estimation and improper designing. Tadewos and Patel [16] carried research on the main cost overrun factors in road projects of Ethiopia. Outcomes of the research highlighted financial issues, land acquisition issues, inadequate planning, delay in supply of materials by contractor, inadequate design and poor management in Australia as the major contributors to cost overrun. Shah et. al. [17] determined the causative cost overrun factors in large construction projects by using a quantitative method. Results of the study revealed that causative and critical cost overrun factors were poor planning and monitoring, construction method, poor monitoring by consultant and fluctuation in materials price. Johnson and Babu [18] explored the severe factors of cost overrun in all construction projects in the United Arab Emirates. The research identified that five major cost overrun factors were design changes, mistakes in cost estimation, delay in deciding by the client, financial controls by the client and unsuitable method of procurement. Haslinda et. al. [19] conducted research on the main factors which contribute to cost overrun in construction projects of Penang in Malaysia by floating a questionnaire among construction stakeholders. The survey showed that the main cost overrun factors were inaccurate cost estimation, cost inflation, sparse pre-construction budget estimation and inaccurate quality standards.

Shaikh et. al. [20] carried a study on the major causes of cost overrun and time overrun by using structured and semi-structured interviews among experts of construction sector. The research showed that slow payment, financial issues and design changes were major causes of cost and time overrun.

The literature review helped to identify 33 main cost overrun factors in construction sector/construction industry as mentioned in Table 1.

\section{Research Methodology}

To achieve the main objectives of this research, a mixed-mode approach (a combination of qualitative and quantitative approach) was used. A comprehensive literature review was conducted on construction cost overrun, which concluded thirty three common cost overrun factors in construction projects. The recognized common cost overrun factors were used to develop a questionnaire. The developed questionnaire 


\begin{tabular}{|c|c|c|c|c|c|c|c|c|}
\hline No & Factors & Ref & No & Factors & Ref & No & Factors & Ref \\
\hline 01 & $\begin{array}{l}\text { Late in making } \\
\text { the decision }\end{array}$ & {$[1]$} & 12 & $\begin{array}{l}\text { Poor site supervision } \\
\text { and management }\end{array}$ & {$[10]$} & 23 & $\begin{array}{l}\text { Inadequate experience } \\
\text { of designers }\end{array}$ & {$[10]$} \\
\hline 02 & $\begin{array}{l}\text { Deviations in the } \\
\text { scope of projects }\end{array}$ & {$[21]$} & 13 & $\begin{array}{l}\text { Delayed payment to } \\
\text { suppliers by contractors }\end{array}$ & {$[21]$} & 24 & $\begin{array}{l}\text { Problems in contract } \\
\text { management }\end{array}$ & [8] \\
\hline 03 & $\begin{array}{l}\text { Late in payment from } \\
\text { owner/client }\end{array}$ & {$[10]$} & 14 & Poor project management & [8] & 25 & Labour issues & {$[21]$} \\
\hline 04 & $\begin{array}{l}\text { Poor coordination } \\
\text { between stakeholders }\end{array}$ & {$[1]$} & 15 & $\begin{array}{l}\text { Delay in materials } \\
\text { delivery }\end{array}$ & {$[1]$} & 26 & Inflation in the market & {$[10]$} \\
\hline 05 & $\begin{array}{l}\text { Delay in approval of } \\
\text { design documents }\end{array}$ & {$[20]$} & 16 & $\begin{array}{l}\text { Shortage of required } \\
\text { materials }\end{array}$ & {$[20]$} & 27 & Floods and Rains & [1] \\
\hline 06 & $\begin{array}{l}\text { Frequent changes in } \\
\text { design by the client }\end{array}$ & {$[10]$} & 17 & Uncertainty at site & {$[21]$} & 28 & $\begin{array}{l}\text { Shortage of skillful } \\
\text { labor }\end{array}$ & {$[20]$} \\
\hline 07 & $\begin{array}{l}\text { Impractical project } \\
\text { schedule }\end{array}$ & {$[12]$} & 18 & $\begin{array}{l}\text { Slow permits by local } \\
\text { authorities }\end{array}$ & {$[8]$} & 29 & $\begin{array}{l}\text { Remote construction } \\
\text { area }\end{array}$ & {$[12]$} \\
\hline 08 & $\begin{array}{l}\text { Inexperienced } \\
\text { contractor }\end{array}$ & {$[21]$} & 19 & $\begin{array}{l}\text { Lack of advanced } \\
\text { equipment and machinery }\end{array}$ & {$[10]$} & 30 & $\begin{array}{l}\text { Incomplete design and } \\
\text { drawings at the time } \\
\text { of tender }\end{array}$ & {$[21]$} \\
\hline 09 & $\begin{array}{l}\text { Poor management by } \\
\text { the contractor at site }\end{array}$ & {$[1]$} & 20 & $\begin{array}{l}\text { Incompetency of } \\
\text { consultant }\end{array}$ & {$[13]$} & 31 & $\begin{array}{l}\text { Transfer of funds from } \\
\text { one project to another } \\
\text { project }\end{array}$ & {$[20]$} \\
\hline 10 & $\begin{array}{l}\text { Financial challenges and } \\
\text { crisis faced by the contractor }\end{array}$ & {$[12]$} & 21 & $\begin{array}{l}\text { Budget issues faced } \\
\text { by the client }\end{array}$ & [1] & 32 & Inadequate planning & {$[13]$} \\
\hline 11 & $\begin{array}{l}\text { Variation in materials } \\
\text { price }\end{array}$ & {$[21]$} & 22 & $\begin{array}{l}\text { Inexperience } \\
\text { sub-contractor }\end{array}$ & {$[21]$} & 33 & $\begin{array}{l}\text { Client interruption } \\
\text { during construction }\end{array}$ & [1] \\
\hline
\end{tabular}

TABLE 1: List of common factors

has two portions: Portion A and Portion B. Portion A was designed to get demography of the respondents. Whereas, portion $\mathrm{B}$ comprised the common construction cost overrun factors. For determination of the level of significance for cost overrun, a five-point Likert Scale was used. Likert scale was designed with values such that 5 indicates "highly contributing", 4 indicates "very contributing", 3 indicates "moderately contributing", 2 indicates "slightly contributing", and 1 indicates "ex-tremely not contributing".

To know the relevancy of cost overrun in the construction sector of Pakistan, a pilot study was conducted among forty highly qualified and experienced stakeholders. Ullah et. al. [21] suggested the cut-off value for relevancy of cost overrun, as presented in Table 2. After analysis of the pilot study, the factors whose value were above 3.0 were known relevant to the construction sector of Pakistan. After conducting a pilot study, the developed questionnaire sets were distributed among 180 stakeholders of Pakistan construction sector. A total of 132 questionnaires sets were received back from selected stakeholders, from which 124 were considered as a valid response. $73 \%$ was the response rate for the conducted survey. The demography of the selected stakeholders for the conducted surveys is presented in Figure 1 and 2. SPSS Statistics is a software package used for interactive or batched statistical analysis. SPSS software was used for analysis of the collected data. Ranking of the cost

\begin{tabular}{|l|l|}
\hline Mean value & Level of Relevancy \\
\hline 3.0 and above & Relevant \\
\hline Less than 3.0 & Not Relevant \\
\hline
\end{tabular}

TABLE 2: Cutoff value

overrun factors is done with mean value.

For determination of mitigation and control measures of identified main cost overrun factors, interviews and discussions were carried out with selected stakeholders and experts of the construction sector of Pakistan. The digital voice recorder was used to record the interviews of the selected stakeholders. Afterwards, NVivo software was used to analysis the collected data. The comprehensive demography of interviewees is shown in Table 3.

\section{Data Analysis \& Discussion}

Following sections present the results of our analysis.

\subsection{Main Cost Overrun Factors}

In this research, SPSS Version 23.0 was used for data analysis. To check the reliability and consistency of the data, the value of Cronbach's alpha was checked. According to Bhandari et. al. [22], the value of Cronbach's alpha should be more than 0.7 . In this research, the value of Cronbach's alpha is greater than 0.7, which indicates that the collected data of the survey is 


\begin{tabular}{|l|l|l|}
\hline Position & Association/ Organization & Total Experience \\
\hline Chief Resident Engineer & Consultant/ Designer & 27 years \\
\hline General Manager & Client/ Owner & 27 years \\
\hline Resident Engineer & Consultant/ Designer & 25 years \\
\hline Resident Engineer & Consultant/ Designer & 25 years \\
\hline Project Director & Client/Owner & 25 years \\
\hline Construction Manager & Consultant/ Builder & 24 years \\
\hline Project Manager & Consultant/ Builder & 24 years \\
\hline Design Engineer & Consultant/ Designer & 22 years \\
\hline Project Manager & Consultant/ Builder & 22 years \\
\hline Project Director & Client/ Owner & 20 years \\
\hline Construction Manager & Consultant/ Builder & 20 years \\
\hline Resident Engineer & Consultant/ Designer & 19 years \\
\hline Director & Client/Owner & 19 years \\
\hline The Engineer & Consultant/ Designer & 18 years \\
\hline Project Manager & Consultant/ Builder & 17 years \\
\hline Project Director & Client/ Owner & 17 years \\
\hline Construction Manager & Consultant/ Builder & 16 years \\
\hline Project Coordinator & Client/ Owner & 16 years \\
\hline Deputy Project Manager & Consultant/ Builder & 15 years \\
\hline Project Engineer & Client/Owner & 15 years \\
\hline
\end{tabular}

TABLE 3: Demography of Interviewees

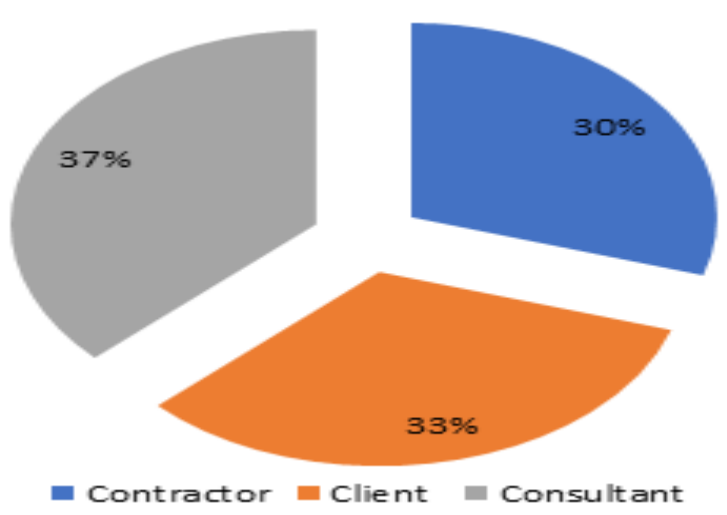

Fig. 1: Response of each stakeholder

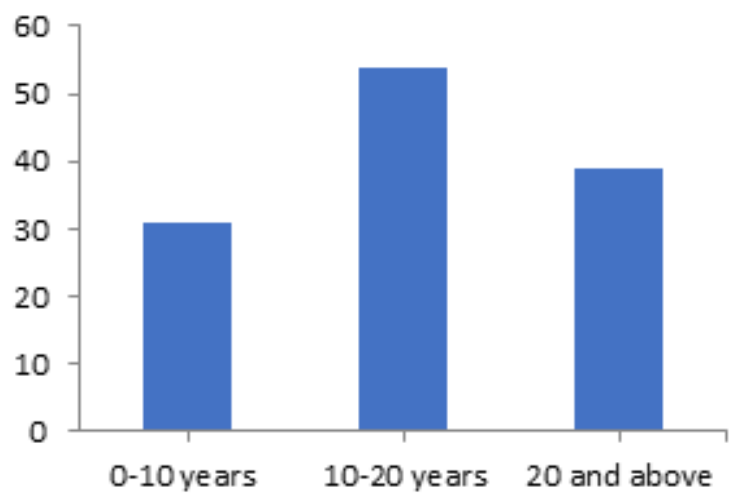

Fig. 2: Working experience of stakeholders accurate and valid. According to Sohu et. al. [23], the factors or causes having score more than 3.6 can be considered as critical factor. Factors that have mean value greater than 3.6 were selected as major cost overrun factors. The mean value of each major factor contributing to cost overrun in the construction sector is shown in Table 4.

\subsection{Mitigation and Controlling Measures for Ma- jor Cost Overrun Factors}

Following are the results of the questionnaire survey, mitigation and control measures of major 11 cost overrun factors explored by conduction interviews from construction stakeholders having expertise on dealing with mega projects. Table 5 shows the mitigation and controlling measures for major 11 cost overrun factors recognized through analysis of data using famous software known as NVivo. The results of the survey determined major 11 cost overrun factors in Pakistan's construction sector. Table 4 shows "Financial challenges and crisis faced by the contractor"found as the first major factor of cost overrun with the maximum mean value of 4.721 . It is also determined that "frequent changes in design by the client" and "deviations in the scope of projects" was found to be second and third most cost overrun factor with the mean value of 4.637 and 4.561 respectively. "Inflation in the market" was classified as fourth major cost overrun factor with the mean value of 4.398. However, "transfer of funds from one project to another project" was rated as fifth major cost overrun factor in Pakistan construction sector.

Mitigation and control measures for major 11 cost 


\begin{tabular}{|l|l|l|}
\hline Major Factors & Mean Value & Ranking \\
\hline Financial challenges and crisis faced by the contractor & 4.721 & 01 \\
\hline Frequent changes in design by the client & 4.637 & 02 \\
\hline Deviations in the scope of projects & 4.561 & 03 \\
\hline Inflation in the market & 4.398 & 04 \\
\hline Transfer of funds from one project to another project & 4.231 & 05 \\
\hline Impractical project schedule & 4.169 & 06 \\
\hline Delay in approval of design documents & 4.066 & 07 \\
\hline Poor coordination between stakeholders & 3.974 & 08 \\
\hline Variation in materials price & 3.894 & 09 \\
\hline Inadequate planning & 3.803 & 10 \\
\hline Poor management by the contractor at site & 3.729 & 11 \\
\hline Resident Engineer & Consultant/ Designer & 19 years \\
\hline Director & Client/Owner & 19 years \\
\hline The Engineer & Consultant/ Designer & 18 years \\
\hline Project Manager & Consultant/ Builder & 17 years \\
\hline Project Director & Client/ Owner & 17 years \\
\hline Construction Manager & Consultant/ Builder & 16 years \\
\hline Project Coordinator & Client/ Owner & 16 years \\
\hline Deputy Project Manager & Consultant/ Builder & 15 years \\
\hline Project Engineer & Client/Owner & 15 years \\
\hline
\end{tabular}

TABLE 4: Ranking of major cost overrun factors

overrun factors were determined by conducting interviews from construction stakeholders. The number of mitigation and control measures was determined for each major cost overrun factor. For major cost overrun factor financial challenges and crisis faced by the contractor" the mitigation and controlling recommendation were "project contract should be awarded to financially strong contractor "funds should be released on time to the contractor", "client should expedite the process of payment to the contractor" and "political interruption should be avoided in the project". Likewise, for the second major cost overrun factor "frequent changes in design by the client", the mitigation and controlling measures were "proper investigation should be made on-site", "expert team of designing should be hired" and "consultant should be appointed on basis of expertise". Each critical factor of cost overrun has strategy of controlling factors by using implementation of suggested measures.

\section{Conclusion}

The construction sector is facing problem of cost overrun since many decades. The impact of this cost overrun leads to slowing down the final completion of construction projects. The changes in cost overruns causes both project management and technical related issues. Cost overrun has badly affected the performance of the construction sector which puts negative affect on the stakeholders of this sector. The main purpose of this research is to identify the critical factors which causes cost overrun in construction sector and also determination of measures for identified critical cost overrun factors. 11 critical factors were identified from total 33 common factors of cost overrun. This research also helps in determination of controlling measures of the critical factors of cost overrun and can be useful for construction stakeholders in Pakistan.

\section{References}

[1] Iqbal, A., Rehman, H. S. U., Munir, M., Ashiq, M., Omar, A., Haider, Z. \& Jahanzaib, M. "Time and Cost Overrun in Construction Projects of Pakistan." Pakistan Journal of Engineering and Technology, Vol. 2, No. 2, pp. 22-29, 2019

[2] Zafar, I., Wuni, I. Y., Shen, G. Q., Ahmed, S., \& Yousaf, T. "A fuzzy synthetic evaluation analysis of time overrun risk factors in highway projects of terrorism-affected countries: the case of Pakistan." International Journal of Construction Management, pp. 1-19, 2019.

[3] Mitra, J. P., Shrestha, J., Ross, J., \& Hong, J. "Analysis of Construction Cost Variation of Construction Manager General Contractor (CM/GC) Pro-ject." In Annual Associated Schools of Construction International Conference, 2019.

[4] Kakumba, M. "Analysis of Cost and Time Overruns during Construction of Public Health Facilities in Uganda: Case Study of World Bank Funded Projects." Doctoral dissertation, Makerere University, 2019.

[5] Ojo, E., Halkias, D., \& Neubert, M. "Project Managers' Capacity-Planning Practices for Infrastructure Projects in Qatar: A Narrative Literature Review." Available at SSRN 3513774, 2020.

[6] Rahman, I. A., Foo, L. C., Memon, A. H., \& Nagapan, S. "Schedule and costt behavior in construction works of Malaysia." Pakistan Journal of Science, Vol. 71, No. 4, pp. 74-77, 2019.

[7] Narayanan, S., Kure, A. M., \& Palaniappan, S. "Study on Time and Cost Overruns in Mega Infrastructure Projects in India." Journal of The Institution of Engineers (India): Series A, Vol. 100, No. 1, pp. 139-145, 2019 


\begin{tabular}{|c|c|c|}
\hline Major Factors & Controlling and mitigation measure & Ranking \\
\hline $\begin{array}{l}\text { Financial challenges and } \\
\text { crisis faced by the contractor }\end{array}$ & $\begin{array}{l}\text { 1. A project contract should be awarded } \\
\text { to Financially strong contractor. } \\
\text { 2. Funds should be released } \\
\text { on time to the contractor } \\
\text { 3. The client should expedite the } \\
\text { process of payment to the contractor } \\
\text { 4. Political interruption should be avoided in the project }\end{array}$ & 01 \\
\hline $\begin{array}{l}\text { Frequent changes in design } \\
\text { by the client }\end{array}$ & $\begin{array}{l}\text { 1. A proper investigation should be made on site } \\
\text { 2. An expert team of designing should be hired } \\
\text { 3. The consultant should be appointed based on expertise }\end{array}$ & 02 \\
\hline $\begin{array}{l}\text { Deviations in the scope } \\
\text { of projects }\end{array}$ & $\begin{array}{l}\text { 1. The political interruption should be avoided } \\
\text { 2. The proper scope of the project } \\
\text { should be defined in the initial stage } \\
\text { 3. The regular meeting should be } \\
\text { arranged with stakeholders }\end{array}$ & 03 \\
\hline Inflation in the market & $\begin{array}{l}\text { 1. The material should be ordered in bulk } \\
\text { 2. Domestic material should be used in the project } \\
\text { 3. The client should make an agreement } \\
\text { with contractor about fix rate of the materials. }\end{array}$ & 04 \\
\hline $\begin{array}{l}\text { Transfer of funds from } \\
\text { one project to another project }\end{array}$ & $\begin{array}{l}\text { 1. Involvement of the political parties } \\
\text { in the project should be restricted } \\
2 \text {. Top management of the project should } \\
\text { not be changed frequently } \\
\text { 3. Sufficient allocation of funds should } \\
\text { be reserved for each project }\end{array}$ & 05 \\
\hline Impractical project schedule & $\begin{array}{l}\text { 1. A proper schedule of the project } \\
\text { should be decided by the stakeholders } \\
2 \text {. The construction site should be } \\
\text { visited by the stakeholders } \\
3 \text {. The competent team should be hired by the client }\end{array}$ & 06 \\
\hline $\begin{array}{l}\text { Delay in approval of } \\
\text { design documents }\end{array}$ & $\begin{array}{l}\text { 1. Meetings should be arranged on a regularly basis } \\
\text { 2. Proper documentation should be made for approval } \\
\text { 3. Site conditions should be presented } \\
\text { to competent authorities }\end{array}$ & 07 \\
\hline $\begin{array}{l}\text { Poor coordination } \\
\text { between stakeholders }\end{array}$ & $\begin{array}{l}\text { 1. A mechanism should be decided for regular meetings } \\
\text { 2. Stakeholders of the project should arrange seminars }\end{array}$ & 08 \\
\hline Incompetent sub-contractor & $\begin{array}{l}\text { 1. Extremely experienced sub-contractor should be selected } \\
\text { 2. Quality of the sub-contractor should be monitored } \\
\text { 3. Selection of subcontractor on his previous history }\end{array}$ & 09 \\
\hline Inadequate planning & $\begin{array}{l}\text { 1. The client should make a strategy } \\
\text { before starting the project } \\
\text { 2. Before tendering, site visits should be } \\
\text { done by all stakeholders of the project } \\
\text { 3. All stakeholders should be taken in } \\
\text { confidence before any decision of the project }\end{array}$ & 10 \\
\hline $\begin{array}{l}\text { Poor management by } \\
\text { the contractor at site }\end{array}$ & $\begin{array}{l}\text { 1. The unforeseen condition should be analyzed } \\
\text { 2. An experienced team should be appointed by the contractor } \\
\text { 3. Monitoring should be done by the consultant staff }\end{array}$ & 11 \\
\hline Resident Engineer & Consultant/ Designer & 19 years \\
\hline Director & Client/Owner & 19 years \\
\hline The Engineer & Consultant/ Designer & 18 years \\
\hline Project Manager & Consultant/ Builder & 17 years \\
\hline Project Director & Client/ Owner & 17 years \\
\hline Construction Manager & Consultant/ Builder & 16 years \\
\hline Project Coordinator & Client/ Owner & 16 years \\
\hline Deputy Project Manager & Consultant/ Builder & 15 years \\
\hline Project Engineer & Client/Owner & 15 years \\
\hline
\end{tabular}

TABLE 5: Mitigation and controlling measures for major cost overrun factors 
[8] Khabisi, J., Aigbavboa, C., \& Thwala, W. "Causes of cost overruns in public sector construction projects in South Africa." Journal of Construction Engineering and Management, 2019.

[9] Amri, T., \& Marey-Pérez, M. "Towards a sustainable construction industry: Delays and cost overrun causes in construction projects of Oman." Journal of Project Management, Vol. 5, No. 2, pp. 87-102. 2020.

[10] Sohu, S., Memon, B. A., Nagapan, S., \& Bhatti, N. U. K. "Mitigation measures for significant factors instigating cost overrun in highway pro-jects." Civil Engineering Journal, Vol. 4, No. 10, pp. 2338-2344, 2018.

[11] Shaikh, F. A. "Financial Mismanagement: A Leading Cause of Time and Cost Overrun in Mega Construction Projects in Pakistan." Engineering, Technology \& Applied Science Research, Vol. 10, No. 1, pp. 5247-5250, 2020.

[12] Wanjari, S. P., \& Dobariya, G. "Identifying factors causing cost overrun of the construction projects in India." Sādhanā, Vol. 41, No. 6, pp. 679-693, 2016.

[13] Akinradewo, O., \& Aigbavboa, C. "Revisiting Causative Factors of Project Cost Overrun in Building Construction Projects in Nigeria." In IOP Conference Series: Materials Science and Engineering, Vol. 640, No. 1, p. 012002, IOP Publishing, 2019.

[14] Albhaisi, M. A. "Factors causing variation orders in construction projects in gaza strip (Case Study: Qatar Projects). Factors Causing Varia-tion Orders in Construction Projects in Gaza Strip." Case Study: Qatar Pro-jects, 2016.

[15] Kim, S. Y., Tuan, K. N., Do Lee, J., \& Pham, H. "Cost overrun factor analysis for hospital projects in Vietnam." KSCE Journal of Civil Engineering, Vol. 22, No. 1, pp. 1-11, 2018.

[16] Tadewos, S. G., \& Patel, D. "Factors influencing Time and Cost Over-runs in Road Construction Projects: Addis Ababa, Ethiopian Scenario." International Research Journal of Engineering and Technology, Vol. 5, No. 1, pp. 177-180, 2018.

[17] Shah, R. K. "An exploration of causes for delay and cost overrun in construction projects: A case study of Australia, Malaysia \& Ghana." Journal of Advanced College of Engineering and Management, Vol. 2, No. 1, pp. 41-55, 2016.

[18] Johnson, R. M., \& Babu, R. I. I. "Time and cost overruns in the UAE construction industry: a critical analysis." International Journal of Construction Management, pp. 1-10, 2016.

[19] Haslinda, A. N., Xian, T. W., Norfarahayu, K., Hanafi, R. M., \& Fikri, H. M. "Investigation on the factors influencing construction time and cost overrun for high-rise building projects in penang." In Journal of Physics: Conference Series, Vol. 995, No. 1, p. 012043, IOP Publishing, 2018.

[20] Shaikh, F. A., Odhano, N., \& Jhatial, A. A. "Financial Issues in Project Schedule of the Construction Industry in Pakistan." Journal of Applied Engineering Sciences, Vol. 10, No. 1, pp. 89-94, 2020.

[21] Ullah, K., Nagapan, S., Sohu, S., \& Khan, M. S. "Measures to mitigate causative factors of budget overrun in Malaysian building projects." International Journal of Integrated Engineering, Vol. 10, No. 9, 2018.

[22] Bhandari, B. K., Pradhan, R. R., Pathak, R., Poudyal, S., Paudyal, M. B., Sharma, S., \& Khadga, P. K. "Assessment of Validity of SF 36 Questionnaire Using Nepali Language to Determine Health-related Quality of Life in Patients with Chronic Liver Disease: A Pilot Study." Cureus, Vol. 10, No. 7, 2018.
[23] Sohu, S., Ullah, K., Jhatial, A. A., Jaffar, M., \& Lakhiar, M. T. "Factors adversely affecting quality in highway projects of Pakistan." International Jour-nal of Advanced and Applied Sciences, Vol. 5, No. 10, pp. 62-66, 2018. 